\title{
Assessment of Rajasthan Surface Water Quality During Covid19 Pandemic Lockdown
}

\author{
${ }^{1}$ Govind Singh Chauhan, ${ }^{2}$ Tajuddeen Mustapha, ${ }^{3}$ Auwal Alhassan Musa, ${ }^{4}$ Abubakar Tahir Garba, ${ }^{5}$ Danish Rashid \\ ${ }^{1}$ Assistant Professor, Civil Engg department, Mewar University, Chittorgarh, India \\ 2,3,5 Post Graduate Scholar, Mewar University, Chittorgarh, India \\ ${ }^{4}$ Lecturer, Kano University of Science and Technology, Wudil, Nigeria.
}

\begin{abstract}
This research paper aimed at investigating the effect of the covid19 pandemic lockdown on the surface water (rivers, canals, dams and lakes) quality of Rajasthan state of India.The data was collected from sixty independent monitoring stations control by the State Pollution Control Board;and was analyzed and compared with the result of April of 2019 using the Indian standardfor water quality recommendations (IS: 2296:1992). The result shows that lockdown has contributed immensely to the improvement of the surface water quality.This was due to the reduction of industrials, transportationand other anthropogenic activities that mostly contributed to the release of toxic effluents and gases which lead to the surface water contamination.Therefore, a periodic based assessment should be employed so that the quality level of surface water can be monitored and controlled as well as enforcing laws to both industries, and general public regarding refuse dumping.
\end{abstract}

Keywords:- Lockdown, quality, improvement, surface-water,level

\subsection{INTRODUCTION}

Water is an indispensable part of human lives as it's variously involves in our daily activities from drinking, cooking and other house chores to agricultural and recreational purposes. Surface water constitute of the streams and rivers that collect water during rainfall and empty it into oceans, seas and lakes. These surface water have been the only sources of water especially during the dry season in many parts of the world. However, they in many times contain various organic and chemical constituents which render them unfit to serve their purposes (Simeonov et al., 2003; Neale et al., 2017) as they are known to transport waste waters from the municipal and industrial layouts; and agricultural runoffs containing pesticides and other chemicals. Therefore, the needs to scientifically access their quality and provide user-friendly results to environmental management agencies and general public; cannot be over emphasized as it immeasurably affect human health and rate of agricultural production. This involves assessment of physico-chemical, micro-pollutants and biological contents of the surface water which are affected by rock constituents of the river basin, atmospheric input, climatic settings and human activities. The results of the assessment are then compared with the standard values for drinking and irrigation; given by regulating bodies like the World Health Organization (WHO), United Nation International Children Emergency Fund (UNICEF) and United State Salinity Laboratory among others.

physio-chemical and biological parameters to assess the of ground water quality of the Indore city and its industrial area using water quality index which revealed that the periodic assessment on the water quality of area should be conducted and compared with the relevant standard for drinking water such as Indian standard, WHO standard; in order to have a reliable and controllable source of water supply. The work on water quality indices found that there is no any water quality index that is universally accepted for the surface water assessment. However, there are ongoing discoveries about other parameters by policymakers that can be used to increase the level of dependency on the indices. They further stated that most of indices across the world utilizes the physio-chemical and biological parameters for the quality assessment.

\subsection{PROBLEM STATERMENT}

The lockdown imposed by the government to tackle the spread of the noble covid-19 has led to limited industrial activities. This has considerably affected the rate of water pollution by industrial effluents hence the quality of surface water. Therefore, this research paper aim at comparatively studying the quality of the surface water before and during the lockdown in Rajasthan State.

\subsection{STUDY AREA}

Rajasthan occupies the northwestern part of India and is the largest state (about $10.74 \%$ of the Indian Territory) with a total area of 342, 239 sq. km bounded between latitude 23 03'-30 12' N andlongitude 69 29'-78 17'E. It's bordered in the north and northeast by Haryanaand Uttar Pradesh, in the west and northwest by Pakistan, and in the south-southeast and southwest by Madhya Pradesh and Gujarat States respectively(Zo, 2011). The state is economically thriving on agriculture and mineral resources; remarkably marble and cement. For details see (Chauhan et al., 2020). 


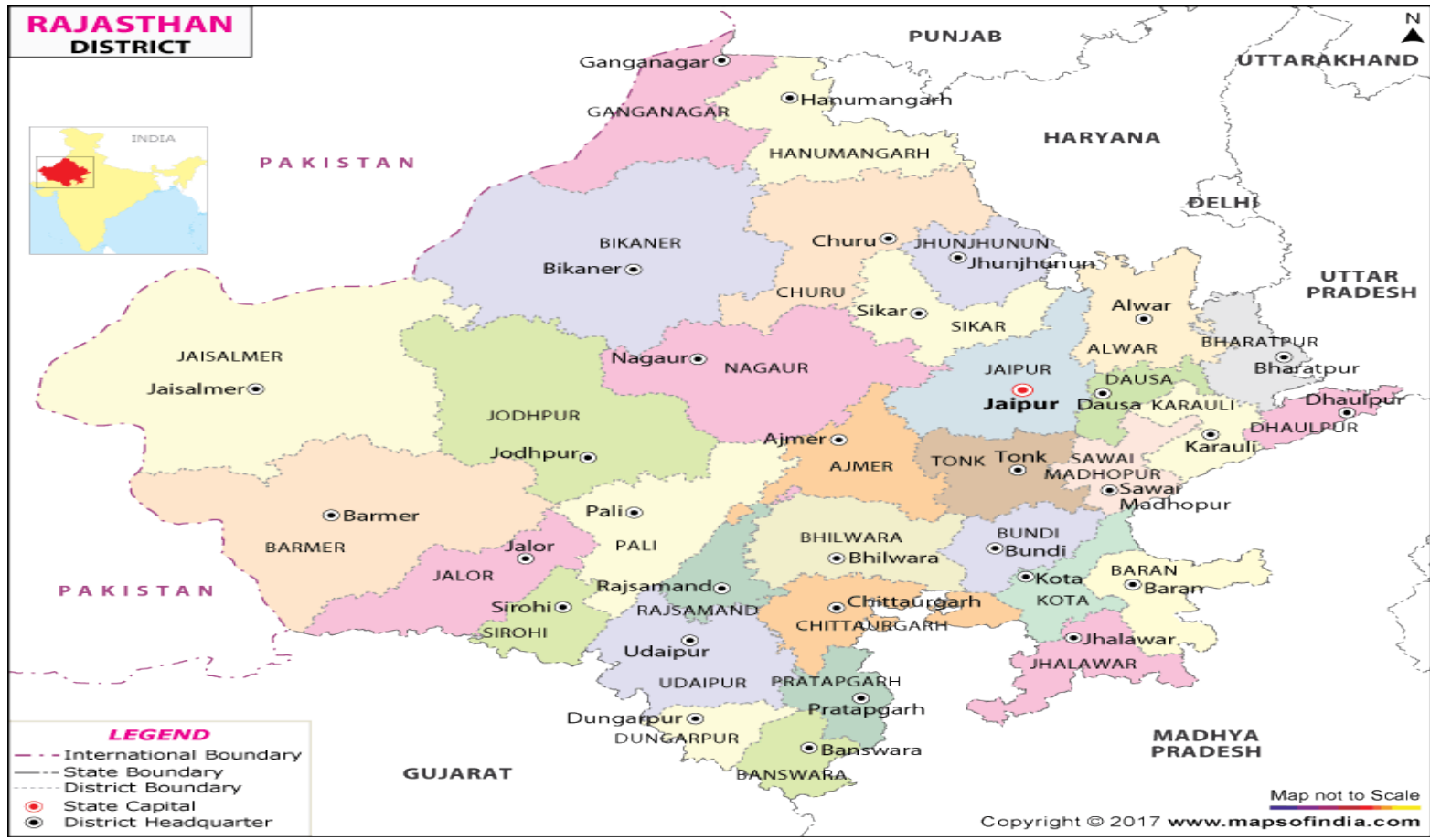

Figure 1: Map of Rajasthan state (Adopted from Chauhan et al., 2020).

\subsection{METHODOLOGY}

The methodology employed in this research involves a comprehensivecomparative analysis madefrom the data collected from the sixty Rajasthan network monitoring stations controlled by the Central Pollution Control Board (CPCB)of the state.The data of water samples were collected and analyzed during the last week of April, 2020.The samples were collected from 14 rivers, 4 canals, 16 lakes and 11 dams, sum up to a total of 45 sources across the state.The analyzed data was compared with the result obtained last year in the same month of April to know the impact of lockdown on surface water quality in the state. The parameters used for this research includes BiochemicalOxygenDemand (BOD), ChemicalOxygenDemand (COD), DissolvedOxygen (DO), Total Coliform andConductivity and the result was compared with the CPCB Water Quality Criteria for Designated Best Use. In order to simplify the work, the analysiswas categorized into two part viz: flowing surface water (Rivers and Canals) and stored surface water (dams and lakes).

For this research work, the codes assigned to each respective water source will be used during the discussion as nomenclature to represent them while the actual names of the sources can be obtained from the Central Pollution Control Board (CPCB)database.

The recommendations made by the Central Pollution Control Board (CPCB)based on bureau of Indian standard (IS 2296:1992)on the quality of surface water were tabulated below:

Table 1:CPCB Water Quality Criteria for Designated Best Use

\begin{tabular}{|c|c|c|}
\hline Designated-Best-Use & Class of Water & Criteria \\
\hline $\begin{array}{l}\text { Drinking Water Source without } \\
\text { conventional treatment but after } \\
\text { disinfection }\end{array}$ & $\mathbf{A}$ & $\begin{array}{l}\text { Total Coliforms Organism MPN/100ml shall be } 50 \text { or less } \mathrm{pH} \\
\text { between } 6.5 \text { and } 8.5 \\
\text { Dissolved Oxygen } 6 \mathrm{mg} / 1 \text { or more } \\
\text { Biochemical Oxygen Demand } 5 \text { days } 20 \mathrm{C} 2 \mathrm{mg} / \mathrm{l} \text { or less }\end{array}$ \\
\hline $\begin{array}{l}\text { Outdoorbathing } \\
\text { (Organised) }\end{array}$ & B & $\begin{array}{l}\text { Total Coliforms Organism MPN/100ml shall be } 500 \text { or less } \mathrm{pH} \\
\text { between } 6.5 \text { and } 8.5 \\
\text { Dissolved Oxygen } 5 \mathrm{mg} / 1 \text { or more } \\
\text { Biochemical Oxygen Demand } 5 \text { days } 20 \mathrm{C} 3 \mathrm{mg} / \mathrm{l} \text { or less }\end{array}$ \\
\hline $\begin{array}{l}\text { Drinking water source after conventional } \\
\text { treatment and disinfection }\end{array}$ & C & $\begin{array}{l}\text { Total Coliforms Organism MPN/100ml shall be } 5000 \text { or less } \mathrm{pH} \\
\text { between } 6 \text { to } 9 \\
\text { Dissolved Oxygen } 4 \mathrm{mg} / 1 \text { or more } \\
\text { Biochemical Oxygen Demand } 5 \text { days } 20 \mathrm{C} 3 \mathrm{mg} / \mathrm{l} \text { or less }\end{array}$ \\
\hline $\begin{array}{l}\text { Propagation } \\
\text { and Fisheries }\end{array} \quad$ of $\quad$ Wild life & D & $\begin{array}{l}\mathrm{pH} \text { between } 6.5 \text { to } 8.5 \\
\text { Dissolved Oxygen } 4 \mathrm{mg} / 1 \text { or more } \\
\text { Free Ammonia (as } \mathrm{N} \text { ) } 1.2 \mathrm{mg} / \mathrm{l} \text { or less }\end{array}$ \\
\hline $\begin{array}{l}\text { Irrigation, Industrial Cooling, Controlled } \\
\text { Waste disposal }\end{array}$ & $\mathbf{E}$ & $\begin{array}{l}\mathrm{pH} \text { between } 6.0 \text { to } 8.5 \\
\text { Electrical Conductivity at } 25 \mathrm{C} \text { micro mhos/cm Max. } 2250 \\
\text { Sodium absorption Ratio Max. } 26 \\
\text { Boron Max. } 2 \mathrm{mg} / \mathrm{l}\end{array}$ \\
\hline
\end{tabular}


Retrieved from Central Pollution Control Board, (CPCB) and Bureau of Indian standard (IS:2296:1992) Ministry of Environment, Forestand Climate Change).

\subsection{The Result of the Flowing Surface Water (Rivers and Canals)}

\subsubsection{Biochemical Oxygen Demand (BOD)}

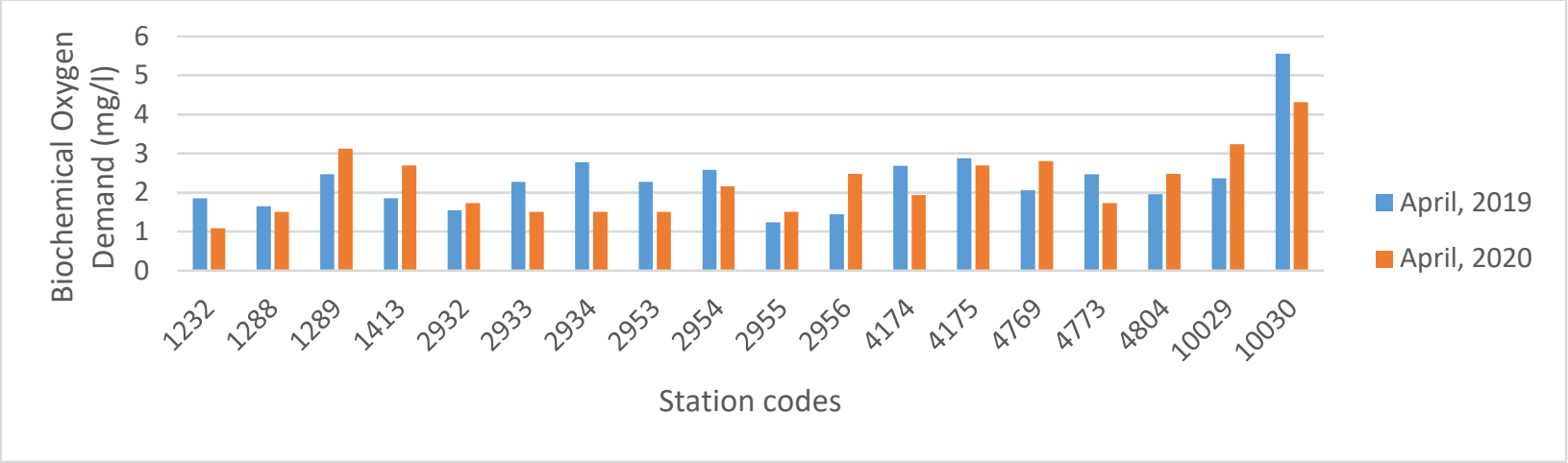

Figure 2: BiochemicalOxygen Demand (BOD)

Results of the assessed BOD in the surface waters (Rivers and Canals) of Rajasthan State before and during the lockdown due to the covid-19 is processed and presented above (Figure 2). It indicated that the BOD ranges between $1.24 \mathrm{mg} / \mathrm{l}$ to $5.56 \mathrm{mg} / \mathrm{l}$ before the lockdown; whereas it ranges between $1.08 \mathrm{mg} / \mathrm{l}$ to $4.32 \mathrm{mg} / \mathrm{l}$ during the lockdown. Generally, there is a considerable decrease in the BOD content except at 1289, 1413, 2932, 2955, 2956, 4769, 4804 and 10029 stations all of which are rivers around Chambal area except 2932 which happened to be Narmada main canal. However, the BOD content at 10030 are exceptionally high both before and during the covid-19 lockdown.Still during the lockdown Using the (IS:2296:1992)recommendations stations 1232, 1288, 2932, 2933, 2934, 2953, 2955, 4174 and 4733, belong to class A, while stations 1413, 2954, 2956, 4175, 4769 and 4804, can be categorized in class B and C. but station 1289, 10029 and 10030 belong to class D.

\subsubsection{Chemical Oxygen Demand (COD)}

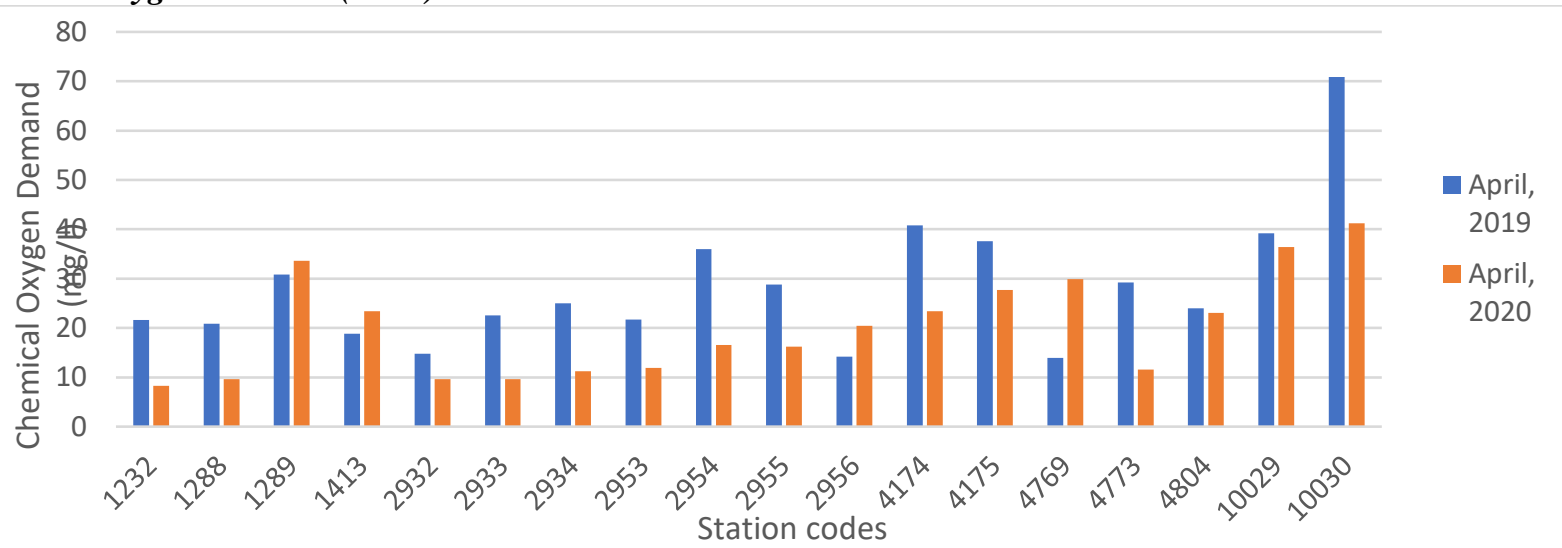

Figure 3: ChemicalOxygen Demand (COD)

Results of the COD contents of the Rivers and Canals in Rajasthan State before and during the lockdown due to the covid-19 pandemic were compared and presented above (Figure 2). It indicated a general decrease in the COD content except at 1289, 1413 and 2956 stations. Similar to the BOD, the highest COD content both before and during the lockdown was recorded at station 10030 whereas the lowest COD contents were recorded at stations 4769 and 1232; before and after the lockdown respectively.No recommendation giving by (IS: 2296:1992)regarding the content of (COD). 


\subsubsection{Dissolved Oxygen (DO)}

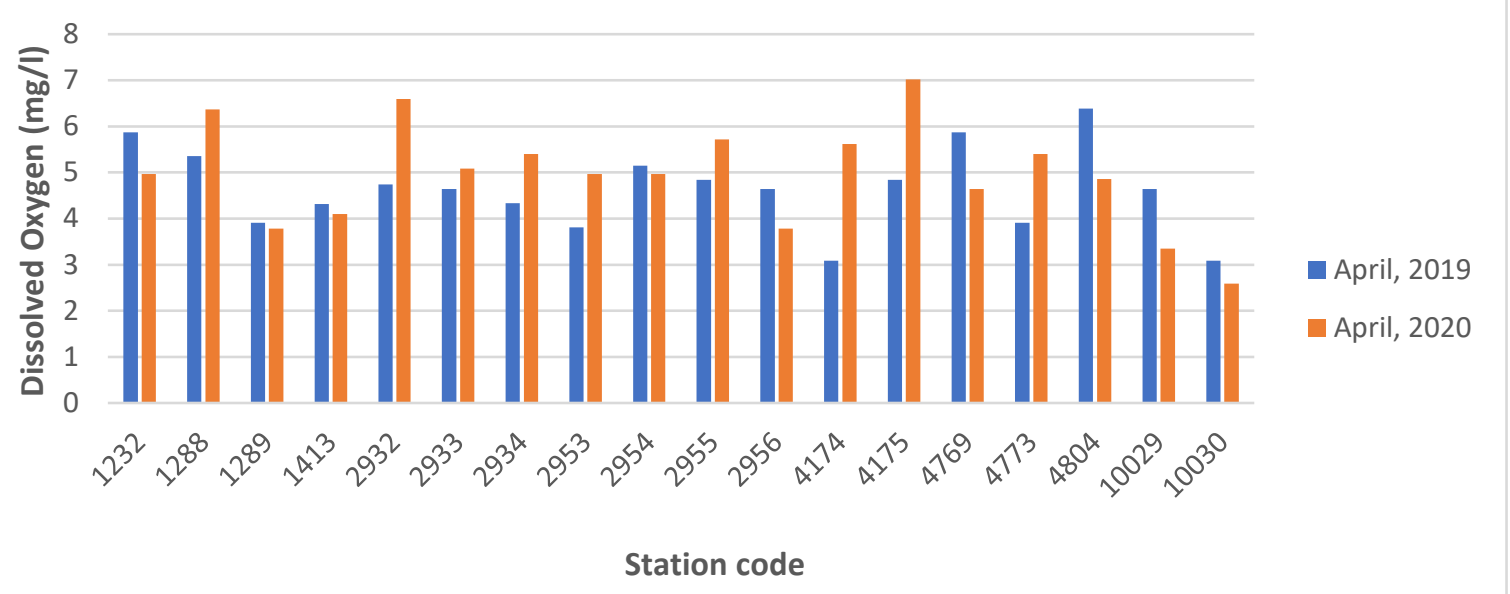

Figure 4: Dissolved Oxygen (DO)

The DO contents of the Rivers and Canalsin Rajasthan before and during the covid-19 lockdown is shown above (Figure 3). Highest DO values were recorded at 10029 and 4175 stations before and during the lockdown respectively; whereas lowest DO values were recorded at 4174 and 10030 before the lockdown and at 10030 during the lockdown. The highest percentage increase was recorded at station $4174(82 \%)$ while the highest percentage decrease was recorded at station 10029. In general, decrease in DO was recorded in nine (9) station while increase in the other nine (9). Considering the (IS: 2296:1992) recommendations during lockdown station 1288, 2932, and 4175 belong to class A, while station 2933, 2934, 2955, 4174, 4773, belong to class B and stations 1232, 1413, 2953, 2954, 4769, 4804. However, the remaining stations of 1289, 2956, 10029, 10030 are of class D.

\subsubsection{Total Coliform}

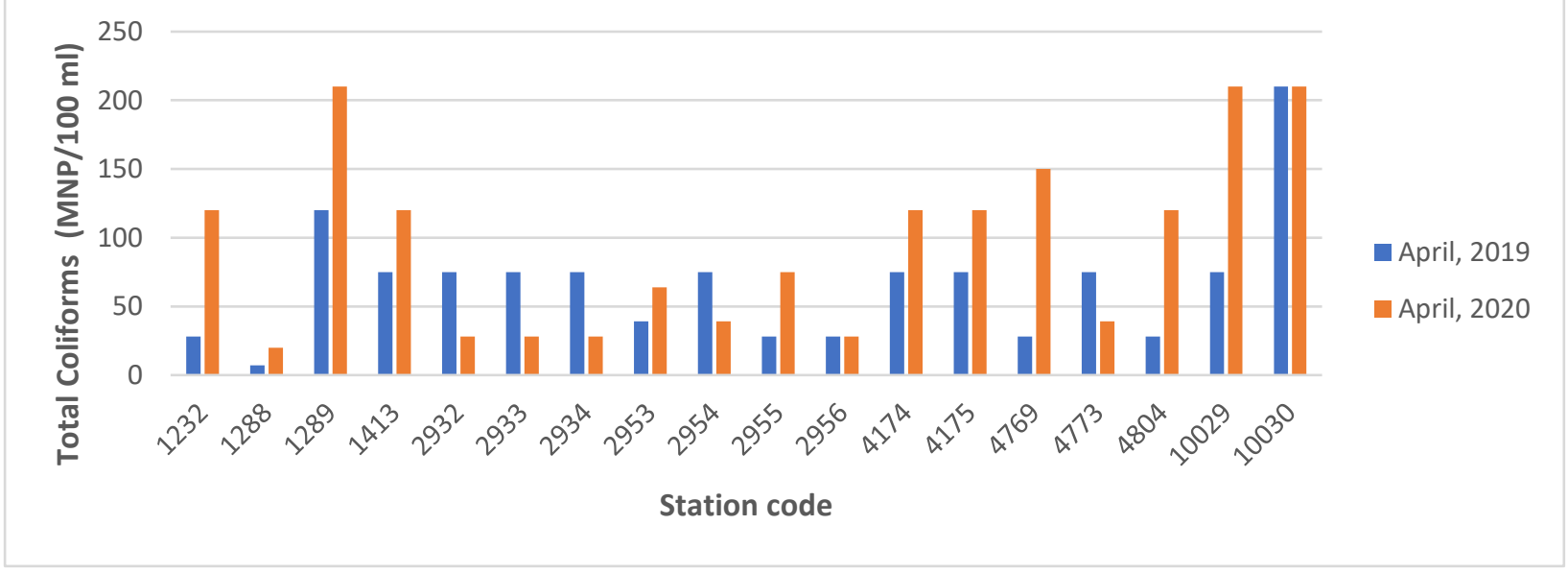

Figure 5: Total Coliforms

The total coliform present in the water bodiesof Rajasthan state before and during the lockdown are compared above (Figure 4). It ranges between 7 to $210 \mathrm{mg} / \mathrm{l}$ before the lockdown and 20 to $210 \mathrm{mg} / \mathrm{l}$ during the lockdown. Before the lockdown, the highest total coliform content was recorded at station $10030(210 \mathrm{mg} / \mathrm{l})$ while the lowest was at station $1288(7 \mathrm{mg} / \mathrm{l})$. During the lockdown, the highest total coliform content was recorded at the stations 1289,10029 and $10030(210 \mathrm{mg} / \mathrm{l})$ while the lowest was recorded at station $1288(20 \mathrm{mg} / \mathrm{l})$. It should be noted that the two lowest values before and during the lockdown were recorded at the same station (1288) and that the total coliform content at station 10030 was the same before and during the lockdown. The value coliform based on the IS recommendationsduring the lockdown of stations 1288, 2932, 2933, 2934, 2954, 2956, 4773, are in class A while all the remaining stations are in class B. 


\subsubsection{Conductivity}

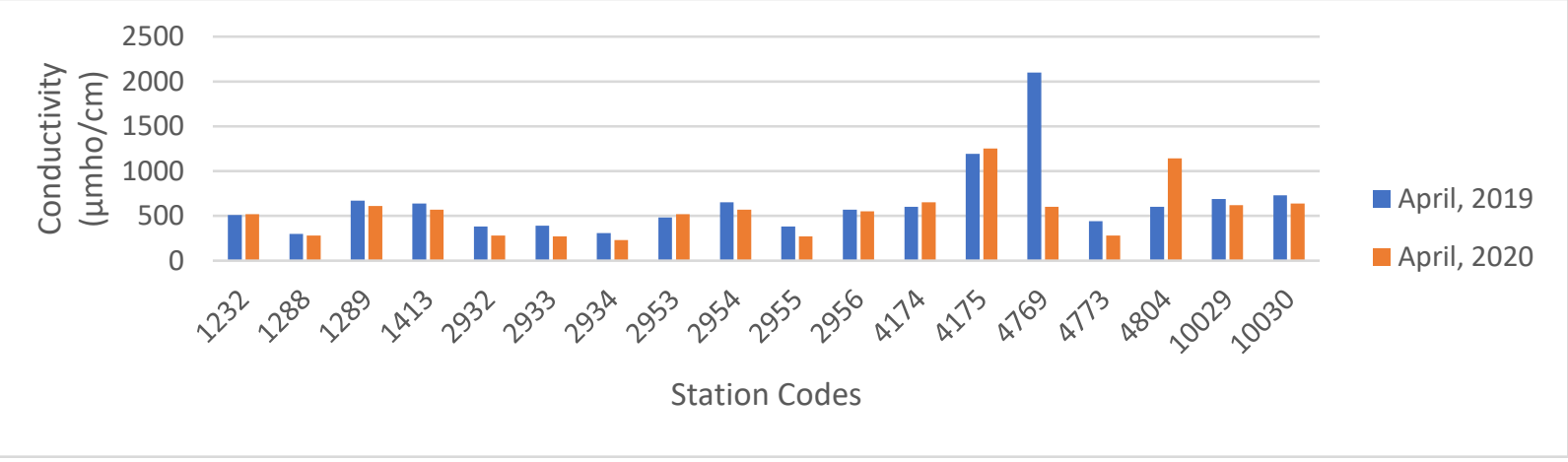

Figure 6: Conductivity

The results of conductivity assessedfromRivers and Canalsof Rajasthan state before and during the covid-19 lockdown were compared above (Figure 5). The conductivity values ranged between 300 to $2100 \mu \mathrm{mho} / \mathrm{cm}$ before the lockdown and between 230 to $1250 \mu \mathrm{mho} / \mathrm{cm}$ during the lockdown. There has generally been a decrease in the conductivity values across all the stations except at 1232, 2953, 4174 and 4804 . The decrease in the conductivity values can be attributed to the decrease in the rate of discharge of industrial effluents into the waterways due to the halt in or extremely reduced industrial activities as a result of covid-19 lockdown. The exceptionally high percentage increase recorded at station 4804 (90\%) may be due to the non-stop of industrial activities in the area or other local factors.

\subsection{RESULT OF THE STORED SURFACE WATER (DAMS AND LAKES)}

\subsubsection{Biochemical Oxygen Demand (BOD)}

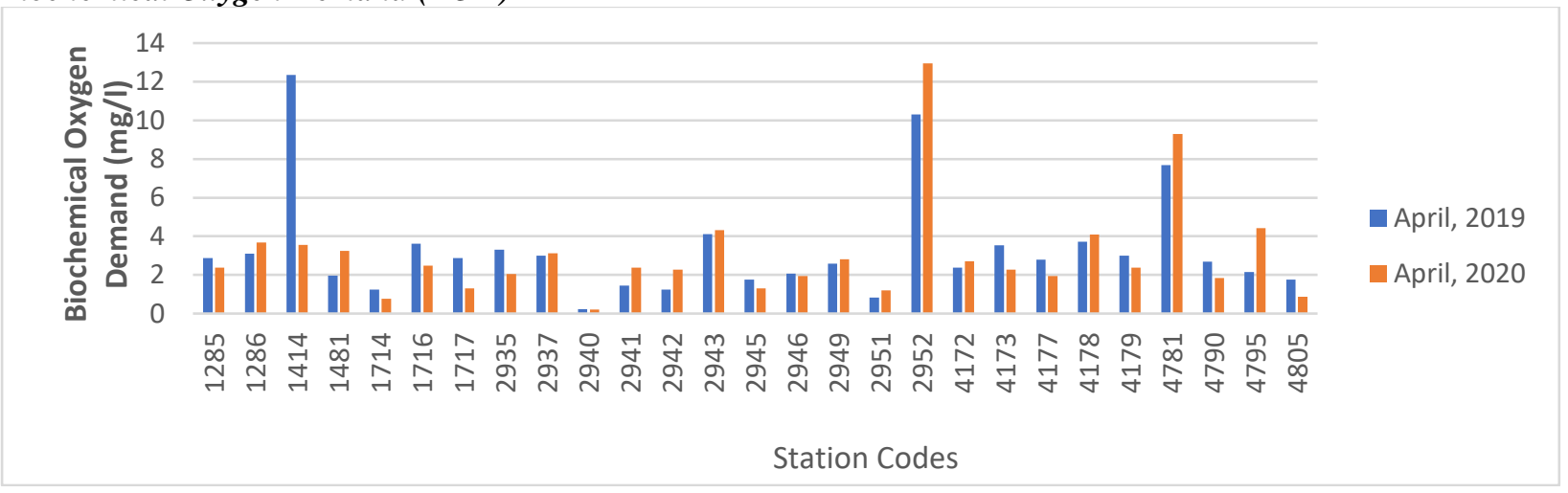

Figure 7: BiochemicalOxygen Demand (BOD)

From the result presented above it can be seen that some stations'BODhave increased while some have decreasedduring the lockdown.The following stations showed decrease in biological oxygen demand 1285, 1414, 1714, 1716, 1717, 2935, 2945, 2946, 4173, 4177, 4179, 4790, 4805. While the remaining stations showed an increase in the biological oxygen demand. Also considering therecommendation made by the bureau of Indianstandard of water qualitystations 1714, 1717, 2940, 2945, 2946, 2951, 4177, 4790 and 4805 are within class A while, 1285,1716, 2935, 2941, 2942, 2949, 4172, 4173, 4179 are within the class B.However, the remaining stations need a series of disinfection and treatment before they can be regarded suitable for human consumption. As they fell within the D class and only 2952 and 4781 belong to group E as their content reaches 12.96 and $9.29 \mathrm{mg} / \mathrm{l}$ respectively. 


\subsubsection{Chemical Oxygen Demand (COD)}

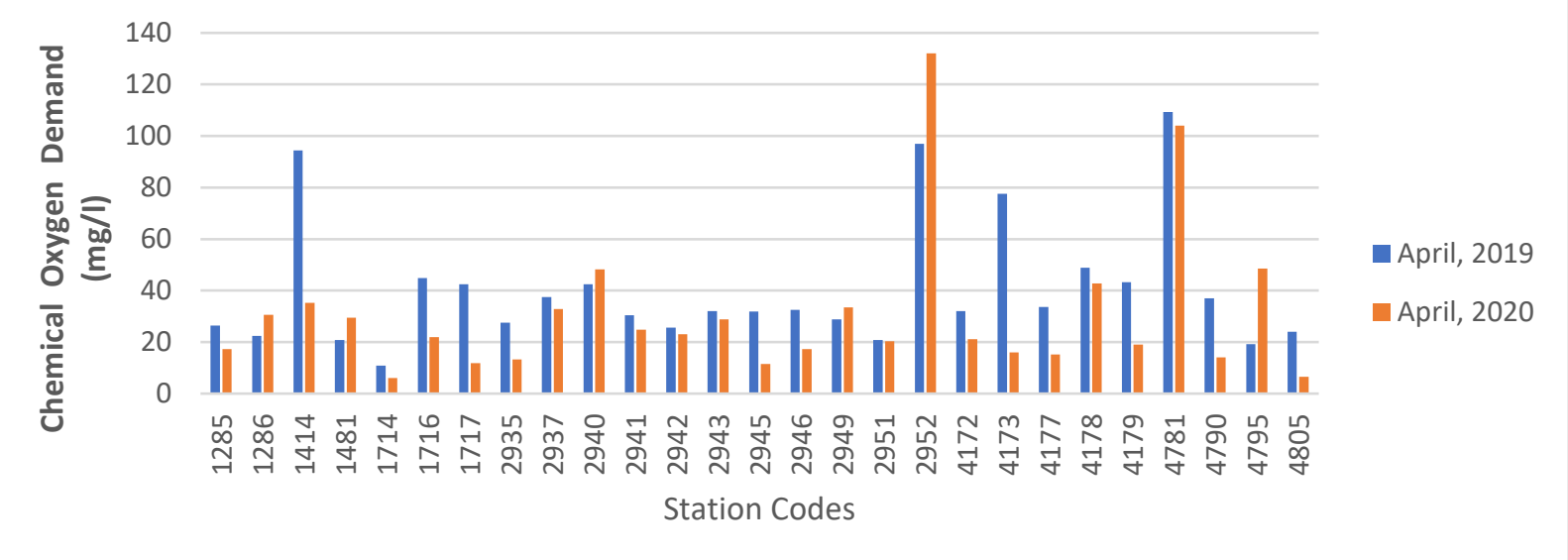

Figure 8: ChemicalOxygen Demand (COD)

With regard to the chemical oxygen demand of Dams and Lakesin Rajasthan statewhich was presented above it can be seen thatStations 1285, 1414, 1714, 1716, 1717, 2935, 2937, 2941, 2942, 2943, 2945, 2946, 2951, 4172,4173, 4177, 4178, 4179, 4781, 4790 and 4805 experienced decrease in chemical oxygendemand while the remaining station shows increases. Although no recommendation made by the IS about the chemical oxygen demand its value can be related to (BOD).

\subsubsection{Dissolved Oxygen (DO)}

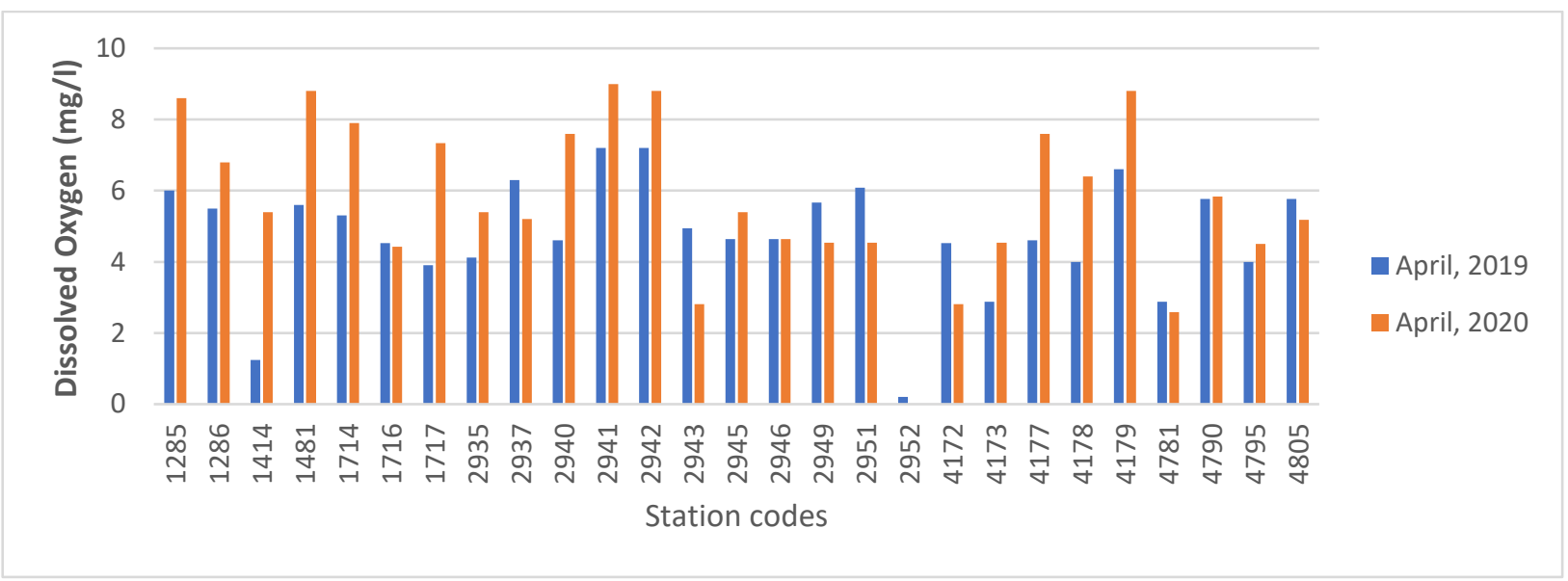

Figure 9: Dissolved Oxygen (DO)

The dissolved oxygen of 1716, 2937, 2943, 2949, 2951, 2952, 4172, 4781 and 4805 stationsdecrease during the lockdown period while all remaining stations show an increase in the dissolved oxygen. the content of the dissolved oxygen of 1285, 1286, 1481, 1714, 1717, 2940, 2941, 2942, 4177, 4178, 4179 are within the class A, while the content of 1414, 2935, 2937, 2945, 4790 , and 4805 belong to class B. the content of 1716, 2946, 2949, 2951, 4173, 4795 are within class C and the remaining station sample belong to classE. 


\subsubsection{Total Coliform}

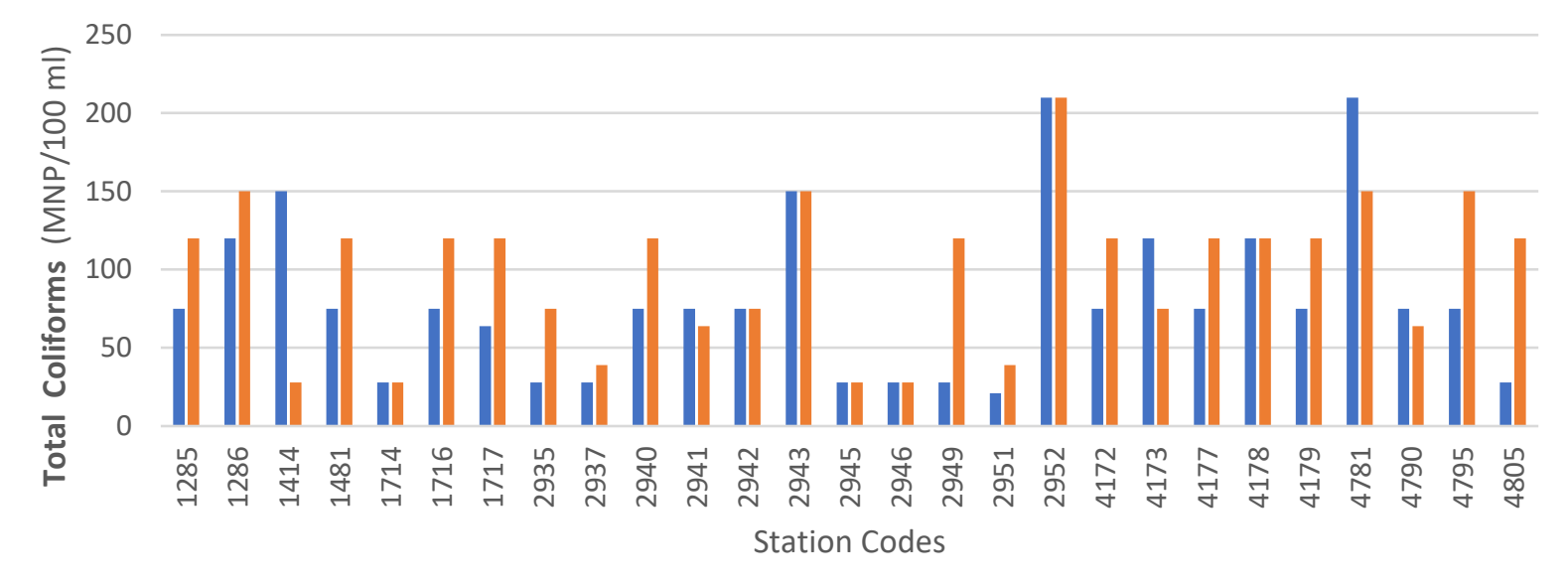

Figure 10: Total Coliforms

The Total Coliforms of stations 1414, 1714, 2937, 2927, 2945, 2946, 2951 belong to class A during lock down which shows an improvement based on IS recommendation while the remaining belong to class B of the Indian Standard of water quality though there is a significant increase of the total coliforms in the following stations 1285, 1286, 1481, 1716, 1717, 2935, 2937 2940, 2949, 2952, 4172, 4177, 4179, 4975, and 4805.Stations 1714, 2942, 2943, 2946, 2952, and 4178 have the same value of total coliformsbefore and during the lockdown while the remaining stations showed decrease in the total coliform values.

\subsubsection{Conductivity}

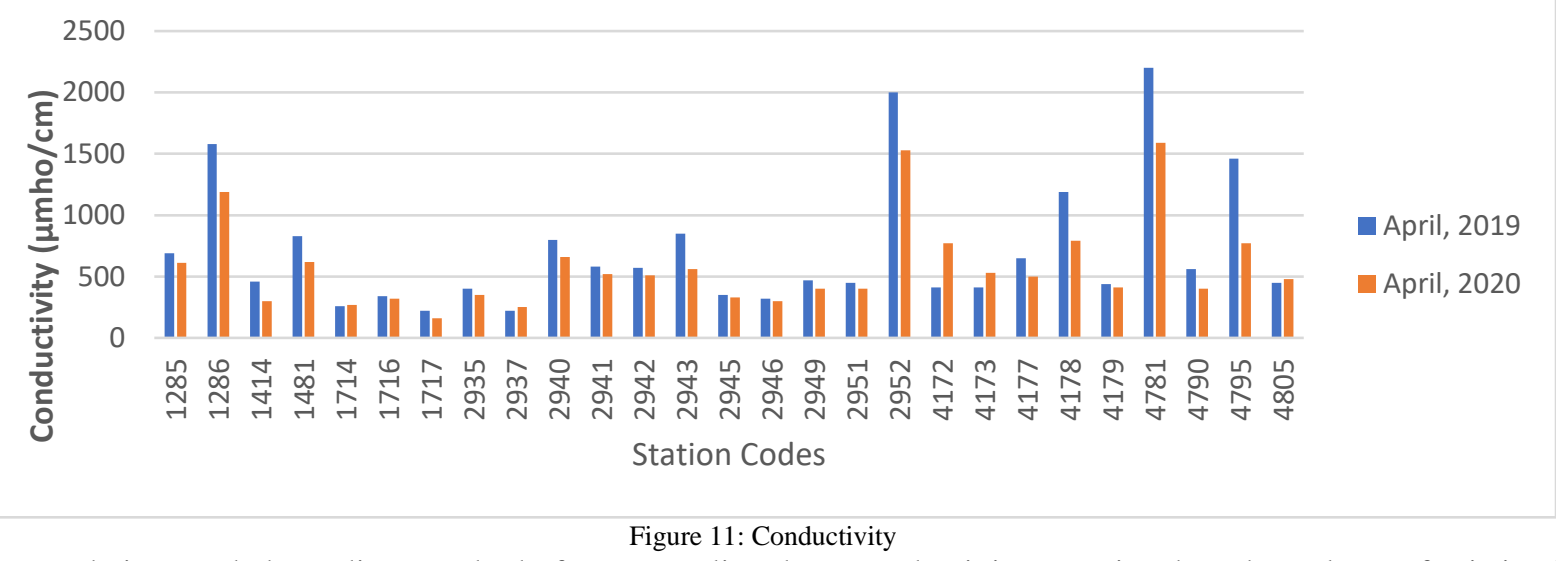

The recommendationsmade by Indian standard of water quality about conductivity were just based on class $\mathrm{E}$ for irrigation and other purposes, while the other classes have no any recommendation. All the conductivityvalues recorded before and during the lockdown are within the range prescribed by the Indian standard.However, there are certain variations noticed among the stations surveyed in which stations 1714, 2937, 4172, 4173, and 4805 have an increased value of conductivity while the remaining stations have decreased values.

\subsection{CONCLUSIONS}

Investigating the quality level of water sources based on certain parameters prescribed byperiodically is of outmost importance. Therefore, based on the above analysis made; the following conclusions were drawn:

1. The quality level of mostof the surface water bodies;both the flowing and stored sources wereremarkablyimproved during the lock down and are within the permissible levels based on the recommendation of Indian standard of water quality. This might be due to the absence or limited industrial and transportation activities which leads to the decrease of industrialeffluentsrelease into the waterways, smoke and gases release from chimneys and combusting engines; hence decrease or increase of the content of these parameters analyzed.Moreover, the lockdown has stopped some anthropogenic activities such as bathing at the river sides, tourist activities at dams and local fishing using chemicals; which considerably lead to increase or decrease of the parameters.

2. Based on the CPCB recommendations, someof the surface water can be used for drinking and other human purposes without any further treatments, while other categories need an additional treatment before used for public purposes. The remaining sources with less qualityi.e. having high contentof contaminants can serve the purposes of irrigation and industries. 


\subsection{RECOMMENDATIONS}

The need fora continuous monitoring of the level of surface water quality is of paramount importance as it has a direct relationship with human health, rate of crops production and other public activities. Therefore,in order to maintain the optimized level of water quality; the following recommendations can be employed by the government agency concerned with the water quality regulation in the state:

1. The release of the toxic effluents and other related pollutants direct to the water bodies especially surface water should be carefully monitoredby the CPCB team. This can be achieved by reducing the level of pollutant concentration before they are release to the waterways from the industrial area.

2. Public enlightment should be made on the dangers associated with inappropriate dumping of refuse and release of waste from household activities to the river or other sources of water; as they lead to the polluting of the surface water and the environment in general.

3. Legislature should be made to ensure strict adherence to the environment rules and regulations.

4. To haveconsistent, reliable and high-quality level of water, the sessional changes i.e. post and pre monsoon seasons, assessment of water quality in the state should be conducted in the state and the CPCB should provide periodic update about it.

\section{REFERENCES}

[1] ArivoliAppavu, SathiamoorthiThangavelu, Satheesh Kumar Muthukannan, Joseph SahayarayanJesudoss And BoomiPandi (2016) Study of Water Quality Parameters of Cauvery River Water in Erode Region Journal of Global Biosciences Volume 5, Number 9, 2016, pp. 4556-4567

[2] Bouslah S., Djemili L., Houichi L. 2017. Water quality index assessment of Koudiat Medouar Reservoir, northeast Algeria using weighted arithmetic index method. Journal of Water and Land Development. No. 35 2017, No. 35 (X-XII) p. 221-228. DOI: 10.1515/jwld-2017-0087.

[3] Brief Report on Impact of Lockdown Due to Covid-19 Pandemic on Surface Water Quality of Rajasthan. Rajasthan State Pollution Control Board, April, 2020.

[4] Bureau of Indian standard (IS: 2296:1992)

[5] Chauhan, S., Musa, A. A., Mustapha, T., Kushwaha, Y., Ameta, D., \& Road, A. (2020). Appraisal of Rajasthan Ambient Air Quality During Covid 19 Pandemic Lockdown. Journal of Xidian University, 14(1001), 5797-5807.

[6] Delpla, I., Jung, A., Baures, E., Clement, M., \& Thomas, O. (2009). Impacts of climate change on surface water quality in relation to drinking water production. Environment International, 35(8), 1225-1233. https://doi.org/10.1016/j.envint.2009.07.001

[7] Devendra Dohare Shriram Deshpande and Atul Kotiya (2014) "Analysis of Ground Water Quality Parameters: A Review". Research Journal of Engineering Sciences Vol. 3 Issue 5, Pp: 26-31, May (2014).

[8] Gurdeep Singh And Rakesh Kant Kamal (2014) "Application of Water Quality Index for Assessment of Surface Water Quality Status in Goa” Current World Environment Vol. 9(3), 994-1000 (2014).

[9] Hiren B. Soni1 And Sheju Thomas (2014) Assessment of Surface Water Quality in Relation to Water Quality Index of Tropical Lentic Environment, Central Gujarat, India International Journal of Environment Volume-3, Issue-1, Dec-Feb 2013/14 Pp 168- 176.

[10] Jyoti Bansal And A. K. Dwivedi (2018) Assessment of ground water quality by using water quality Index and physio chemical parameters: Review Paper International journal of engineering sciences \& research Technology. Vol. 7, Issue. 2, February, 2018 pp170-174.

[11] Kankal, N. C., Indurkar, M. M., Gudadhe, S. K., \& Wate, S. R. (2012). Water Quality Index of Surface Water Bodies of Gujarat , India. 440020(1), $39-48$.

[12] Kaurish, F. W., \& Younos, T. (2007). Developing A Standardized Water Quality Index For Evaluating Surface Water Quality 1. Journal Of The American Water Resources Association, 43(2).

[13] Neale, P. A., Altenburger, R., Aït-aïssa, S., Brion, F., Busch, W., Umbuzeiro, G. D. A., Denison, M. S., Pasquier, D. Du, Hollert, H., Morales, D. A. Novák, J., Schlichting, R., Seiler, B., Serra, H., Shao, Y., Tindall, A. J., Tollefsen, K. E., Williams, T. D., \& Escher, B. I. (2017). Development of a bioanalytical test battery for water quality monitoring: Fingerprinting identified micropollutants and their contribution to effects in surface water. Water Research. https://doi.org/10.1016/j.watres.2017.07.016

[14] Poonam Prasad, MeenalChaurasia, R. A. Sohony, Indrani Gupta, R. Kumar (2013) "Water quality analysis of surface water: A Web approach". Environ Monit Assess (2013) 185:5987-5992.

[15] Sabrina Sorlini 1, Daniela Palazzini 1, Joseph M. Sieliechi 2, Martin B. Ngassoum Assessment of Physical-Chemical Drinking Water Quality in The Logone Valley (Chad-Cameroon) Journal of Sustainability 2013, 5, 3060-3076; doi:10.3390/su5073060 2.

[16] Simeonov, V., Stratis, J. A., Samara, C., Zachariadis, G., Voutsa, D., Anthemidis, A., Sofoniou, M., \& Kouimtzis, T. (2003). Assessment of the surface water quality in Northern Greece. 37, 4119-4124. https://doi.org/10.1016/S0043-1354(03)00398-1

[17] Shrestha, S., \& Kazama, F. (2007). Assessment of surface water quality using multivariate statistical techniques : A case study of the Fuji river basin , Japan. Environmental Modelling \& Software, 22, 464-475. https://doi.org/10.1016/j.envsoft.2006.02.001

[18] Sivaranjani S. AmitavaRakshitand Samrath Singh (2015) Water Quality Assessment with Water Quality Indices International Journal of Bioresource Science Vol 21 Issue 21 July 2015 Pp:85-94.

[19] Zhang, B., Song, X., Zhang, Y., Han, D., \& Tang, C. (2012). Hydrochemical characteristics and water quality assessment of surface water and groundwater in Songnen plain , Northeast China. Water Research, 46(8), 2737-2748. https://doi.org/10.1016/j.watres.2012.02.033

[20] Zhang, Z., Tao, F., Du, J., Shi, P., Yu, D., Meng, Y., \& Sun, Y. (2010). Surface water quality and its control in a river with intensive human impacts e a case study of the Xiangjiang River , China. Journal of Environmental Management, 91(12), 2483-2490. https://doi.org/10.1016/j.jenvman.2010.07.002

[21] Zo, I. (2011). Geology And And Mineral Resources Of Rajasthan. 2010. 


\section{AUTHORS PROFILE}

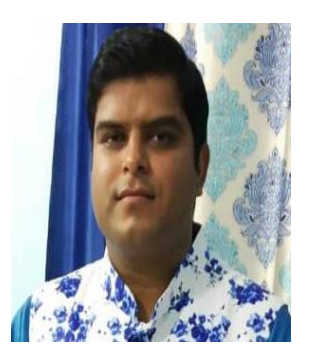

Govind Singh Chauhan: Assistant Professor, Civil Engineering Department, Mewar University, Chittorgarh, India

Auwal Alhassan Musa: Post Graduate Scholar, Civil Engineering Department, Mewar University, Chittorgarh, India 